\title{
Contents and bioconversion of $\beta$-glycoside isoflavones to aglycones in the processing conditions of soybean tempeh
}

\author{
Cristiane Wing Chong Borges ${ }^{(1)}$, Mercedes Concórdia Carrão-Panizzi(2), José Marcos Gontijo Mandarino( ${ }^{(3)}$, \\ Josemeyre Bonifácio da Silva ${ }^{(1)}$, Silvia Benedetti( ${ }^{(1)}$ and Elza louko Ida ${ }^{(1)}$
}

\begin{abstract}
(1)Universidade Estadual de Londrina, Departamento de Ciência e Tecnologia de Alimentos, Rodovia Celso Garcia Cid, PR-445, Km 380, Campus Universitário, Caixa Postal 10.011, CEP 86057-970 Londrina, PR, Brazil. E-mail: criswborges@hotmail.com, josibonifacio@uel.br, silviabene@gmail.com, elida@uel.br (2)Embrapa Trigo, Rodovia BR-285, Km 294, Caixa Postal 451, CEP 99001-970 Passo Fundo, RS, Brazil. E-mail: mercedes.panizzi@embrapa.br ${ }^{(3)}$ Embrapa Soja, Rodovia Carlos João Strass, Acesso Orlando Amaral, Distrito Warta, Caixa Postal 231, CEP 86001-970 Londrina, PR, Brazil. E-mail: josemarcos.gontijo@embrapa.br
\end{abstract}

\begin{abstract}
The objective of this work was to evaluate the effect of the processing conditions of soybean tempeh on the contents of $\beta$-glycoside isoflavones and on their bioconversion into aglycones. Different times of soaking $(6,12$, and 18 hours), cooking $(15,30$, and 45 minutes), and fermentation (18, 24, and 30 hours) with Rhizopus oligosporus at $37^{\circ} \mathrm{C}$ were evaluated for tempeh preparation. Grains from the cultivar 'BRS $267^{\prime}$ were used, and the experiment was carried out according to a central composite design $\left(2^{3}\right)$. The response functions comprised the contents of genistin, malonyldaidzin, malonylgenistin, daidzein, and genistein, quantified by ultraperformance liquid chromatography (UPLC). Soaking, cooking, and fermentation times change the content, profile, and distribution of the different forms of isoflavones in tempeh. The highest bioconversion of glycoside isoflavones into aglycones occurred in 6-hour soaked soybean grains, whose cotyledons were cooked for 15 minutes and subjected to 18 -hour fermentation.
\end{abstract}

Index terms: Glycine max, Rhizopus oligosporus, daidzein, fermented soybean, functional food, genistein.

\section{Conteúdo e bioconversão de isoflavonas $\beta$-glicosídeos em agliconas nas condições de processamento do tempeh de soja}

Resumo - O objetivo deste trabalho foi avaliar o efeito das condições de processamento do tempeh de soja sobre o conteúdo de isoflavonas $\beta$-glicosídeos e sobre sua bioconversão em agliconas. Diferentes tempos de maceração (6, 12 e 18 horas), cozimento (15, 30 e 45 minutos) e fermentação (18, 24 e 30 horas) com Rhizopus oligosporus a $37^{\circ} \mathrm{C}$ foram avaliados na preparação do tempeh. Foram utilizados grãos da cultivar 'BRS 267', e o experimento foi realizado de acordo com um delineamento composto central $\left(2^{3}\right)$. As funções-respostas compreenderam o teor de genistina, malonildaidzina, malonilgenistina, daidzeína e genisteína, quantificadas por cromatografia líquida de ultraeficiência (CLUE). Os tempos de maceração, cozimento e fermentação alteraram o conteúdo, o perfil e a distribuição das diferentes formas de isoflavonas no tempeh. A maior bioconversão de $\beta$-glicosídeos em agliconas ocorreu em grãos de soja macerados por 6 horas, cujos cotilédones foram cozidos por 15 minutos e submetidos à fermentação por 18 horas.

Termos para indexação: Glycine max, Rhizopus oligosporus, daidzeína, soja fermentada, alimento funcional, genisteína.

\section{Introduction}

Tempeh is a traditional Indonesian food of high nutritional quality, obtained by fungal fermentation of dehulled, soaked, and cooked soybean grains (Starzyǹska-Janiszewska et al., 2014). It is commercially available in different forms, such as fried, boiled, steamed or roasted. In general, the tempeh is obtained by fermentation of soybean grains with Rhizopus oligosporus, and it is an excellent protein source that has all the essential amino acids for human nutrition, in addition to dietary fibers, calcium, vitamin B12, folic acid, low sodium content, and unsaturated fats (United States Department of Agriculture, 2008). Moreover, fermented soybean foods contain several health beneficial bioactive compounds (Murooka \& Yamashita, 2008) of which the most important are folate, vitamin B12, and isoflavones (Mo et al., 2013).

The preparation process of soy tempeh includes soaking soybean grains, cooking their cotyledons and fermentating them by the inoculation with Rhizopus 
oligosporus; however, these processes are not standardized. Usually, soybean grains are soaked in water for 10 to 12 hours, at room temperature, in order to facilitate the removal of the hulls. Cotyledons are then cooked in boiling water, drained, cooled at 35 to $40^{\circ} \mathrm{C}$, inoculated with microorganisms, and fermented at $37^{\circ} \mathrm{C}$ for 24 to 48 hours (Nout \& Kiers, 2005). Rhizopus oligosporus is the most often used fungus for fermentation of soybean tempeh, due to its rapid growth between 30 and $42^{\circ} \mathrm{C}$ (Shurtleff \& Aoyagi, 2001).

Fermentation is the major processing stage for obtaining tempeh, due to the changes that occur in the sensory characteristics and chemical composition of the food, mainly associated with the bioconversion of isoflavones (Chang et al., 2009). The fermentation process depends on soybean tempeh processing conditions, such as time, temperature, $\mathrm{pH}$, inoculum amount, and relative moisture content (Nout \& Kiers, 2005). In this stage, $\beta$-glycosidase hydrolyzes $\beta$-glycoside forms to aglycones, which are more bioactive and absorbable isoflavones in the intestine, compared to their glycosidic forms (Izumi et al., 2000; Liggins et al., 2000). Isoflavones, and mainly the aglycones forms, have drawn attention because of their ability to reduce the risk of cardiovascular diseases (Zhuo et al., 2004), to inhibit cancer cell growth (Sarkar \& Li, 2003; Lund et al., 2004), to alleviate the menopause symptoms (Messina \& Hughes, 2003), and to prevent diseases such as osteoporosis (Arjmandi et al., 1996). The bioconversion of $\beta$-glucoside forms into aglycones (daidzein, genistein and glycitein) requires hydrolysis by $\beta$-glycosidase.

Nakajima et al. (2005) concluded that the content of three isoflavones aglycones (daidzein, glycitein and genistein) in soybean tempeh had increased about two times after 24 hours of fermentation. During soybean tempeh processing, glycosides isoflavones are converted to their corresponding aglycones, increasing the concentrations of daidzein and genistein, and decreasing the ones of some isoflavones (Haron et al., 2009). The bioconversion of glycosides isoflavones into aglycones occur during fermentation, with higher contents found after long fermentation times (Villares et al., 2011). Ferreira et al. (2011) showed that the total glycoside forms (daidzin and genistin) in soybean cotyledons decrease, and that the malonyl forms, which react unsteadily to heat treatments, reduced greatly as a result of cooking. These authors also mention that aglycones forms (daidzein and genistein) increase after 24 hours of fermentation. Bavia et al. (2012) observed a $43 \%$ reduction in malonyl forms after cooking soybean grains, and a $50 \%$ increase in the aglycones levels after fermentation.

The objective of this study was to evaluate the effect of the processing conditions of soybean tempeh on the contents of $\beta$-glycosides isoflavones and on their bioconversion into aglycones.

\section{Material and Methods}

Soybean cultivar 'BRS 267' harvested in Londrina, PR, Brazil, in 2011/2012, was used to prepare the soybean tempehs. Lyophilized Rhizopus microsporus var. oligosporus was obtained from Intsoy (International Soybean Program, University of Illinois, EUA). Isoflavone standard solutions were prepared from 6"-O-acetylglucosides and 6"-O-malonylglucosides (Wako Pure Chemical Industries, Ltd., Osaka, Japan), and from $\beta$-glucosides and aglycones (Sigma-Aldrich Co., St. Louis, MO, USA). The other reagents were of analytical grade and obtained from different sources.

To evaluate the effects of tempeh processing variables on the bioconversion of $\beta$-glycoside isoflavones into aglycones, a central composite design $\left(2^{3}\right)$ was used, with 3 replicates of central point, totaling 17 random assays. The tempehs were prepared according to the traditional method described by Wei (1991), with modifications. The following processing variables were investigated: $\mathrm{X} 1$ (soaking time, $\mathrm{h}$ ), $\mathrm{X}_{2}$ (cooking time, $\min$ ), and $X_{3}$ (fermentation time, h). For each assay, $100 \mathrm{~g}$ of soybean grains (proportion 1:10, w/v) were soaked $\left(\mathrm{X}_{1}\right)$, and grains were manually dehulled. Cotyledons were cooked in boiling water $\left(\mathrm{X}_{2}\right)$, and then they were drained and cooled at $25^{\circ} \mathrm{C}$. For the inoculation, $2 \mathrm{~g}$ of $R$. oligosporus were used per $100 \mathrm{~g}$ of cooked and cooled cotyledons. After inoculation, the cotyledons were homogenized, packaged in perforated polypropylene bags, maintained at $37^{\circ} \mathrm{C}$, and fermented $\left(\mathrm{X}_{3}\right)$ according to the experimental design. Table 1 shows the coded and real levels of the independent variables. These levels were established in a preliminary test. The produced tempehs were lyophilised in a freeze-dryer, model Alpha 2-4 LD plus (Martin Christ, Osterode am Harz, Germany) and 
stored at $-26^{\circ} \mathrm{C}$, for the extraction and quantification of isoflavone contents.

The response functions $(\mathrm{Y})$ to different isoflavone forms in tempeh, $\mathrm{Y}_{1}\left(\mu \mathrm{mol}\right.$ genistin $\left.\mathrm{g}^{-1}\right), \mathrm{Y}_{2}(\mu \mathrm{mol}$ malonyldaidzin $\left.\mathrm{g}^{-1}\right), \mathrm{Y}_{3}\left(\mu \mathrm{mol}\right.$ malonylgenistin $\left.\mathrm{g}^{-1}\right), \mathrm{Y}_{4}$ $\left(\mu \mathrm{mol}\right.$ daidzein $\left.\mathrm{g}^{-1}\right)$, and $\mathrm{Y}_{5}\left(\mu \mathrm{mol}\right.$ genistein $\left.\mathrm{g}^{-1}\right)$, were determined according to the following mathematical model:

$\mathrm{Y}=\beta_{0}+\beta_{1} \mathrm{x}_{1}+\beta_{2} \mathrm{x}_{2}+\beta_{3} \mathrm{x}_{3}+\beta_{11} \mathrm{x}_{1}^{2}+\beta_{22} \mathrm{x}_{2}^{2}+\beta_{33} \mathrm{x}_{3}^{2}+\beta_{12} \mathrm{x}_{1} \mathrm{x}_{2}$ $+\beta_{13} x_{1} x_{3}+\beta_{23} x_{2} x_{3}+\varepsilon$

in which: $Y$ is the response function; $x_{1}, x_{2}$, and $x_{3}$ are coded variables; $\beta$ is the estimated coefficient of the response surface model; and $\varepsilon$ is the pure error. The response functions were evaluated by regression analysis and analysis of variance. The equation model was fitted to experimental data to propose the model. Response surface graphs and desirability parameters were generated for each response function, in order to obtain a tempeh with the maximum content of aglycones. All analyses, desirability parameters, and response surfaces were performed with the software Statistica, version 8.0 (StatSoft, Inc.,Tulsa, OK, USA).

Table 1. Components of the central composite design $\left(2^{3}\right)$ and response functions $(\mathrm{Y})$ to different isoflavone forms in tempeh produced with grains of soybean cultivar 'BRS 267'.

\begin{tabular}{lcccccccc}
\hline Assays & $\mathrm{X}_{1}\left(\mathrm{x}_{1}\right)$ & $\mathrm{X}_{2}\left(\mathrm{x}_{2}\right)$ & $\mathrm{X}_{3}\left(\mathrm{x}_{3}\right)$ & $\mathrm{Y}_{1}$ & $\mathrm{Y}_{2}$ & $\mathrm{Y}_{3}$ & $\mathrm{Y}_{4}$ & $\mathrm{Y}_{5}$ \\
\hline 1 & $6(-1)$ & $15(-1)$ & $18(-1)$ & 0.36 & 0.58 & 2.02 & 0.08 & 1.14 \\
2 & $6(-1)$ & $15(-1)$ & $30(+1)$ & 0.33 & 0.49 & 1.72 & 0.09 & 0.93 \\
3 & $6(-1)$ & $45(+1)$ & $18(-1)$ & 0.40 & 0.0 & 0.79 & 0.05 & 0.88 \\
4 & $6(-1)$ & $45(+1)$ & $30(+1)$ & 0.27 & 0.0 & 0.67 & 0.05 & 0.74 \\
5 & $18(+1)$ & $15(-1)$ & $18(-1)$ & 0.13 & 0.42 & 1.49 & 0.07 & 1.11 \\
6 & $18(+1)$ & $15(-1)$ & $30(+1)$ & 0.23 & 0.35 & 1.27 & 0.07 & 0.81 \\
7 & $18(+1)$ & $45(+1)$ & $18(-1)$ & 0.23 & 0.27 & 0.85 & 0.11 & 1.35 \\
8 & $18(+1)$ & $45(+1)$ & $30(+1)$ & 0.29 & 0.0 & 0.67 & 0.06 & 0.74 \\
9 & $6(-1)$ & $30(0)$ & $24(0)$ & 0.28 & 0.36 & 1.27 & 0.09 & 1.12 \\
10 & $18(+1)$ & $30(0)$ & $24(0)$ & 0.28 & 0.30 & 1.10 & 0.09 & 1.12 \\
11 & $12(0)$ & $15(-1)$ & $24(0)$ & 0.15 & 0.48 & 1.73 & 0.09 & 1.20 \\
12 & $12(0)$ & $45(+1)$ & $24(0)$ & 0.27 & 0.0 & 0.67 & 0.06 & 0.77 \\
13 & $12(0)$ & $30(0)$ & $18(-1)$ & 0.25 & 0.31 & 1.11 & 0.07 & 1.16 \\
14 & $12(0)$ & $30(0)$ & $30(+1)$ & 0.22 & 0.29 & 0.99 & 0.06 & 0.77 \\
15 & $12(0)$ & $30(0)$ & $24(0)$ & 0.21 & 0.32 & 1.13 & 0.08 & 1.11 \\
16 & $12(0)$ & $30(0)$ & $24(0)$ & 0.32 & 0.29 & 1.03 & 0.08 & 1.01 \\
17 & $12(0)$ & $30(0)$ & $24(0)$ & 0.22 & 0.39 & 1.15 & 0.08 & 1.11 \\
\hline
\end{tabular}

Coded variables: $\mathrm{x}_{1}, \mathrm{x}_{2}$, and $\mathrm{x}_{3}$. Real variables: $\mathrm{X}_{1}$, hydration time (h); $\mathrm{X}_{2}$, cooking time (min); and $X_{3}$, fermentation time (h). $Y_{1}, \mu$ mol of genistin $\mathrm{g}^{-1}$ of tempeh; $\mathrm{Y}_{2}, \mu \mathrm{mol}$ of malonyldaidzin $\mathrm{g}^{-1}$ of tempeh; $\mathrm{Y}_{3}, \mu \mathrm{mol}$ of malonylgenistin $\mathrm{g}^{-1}$ of tempeh; $\mathrm{Y}_{4}, \mu \mathrm{mol}$ of daidzein $\mathrm{g}^{-1}$ of tempeh; and $\mathrm{Y}_{5}, \mu \mathrm{mol}$ of genistein $\mathrm{g}^{-1}$ of tempeh.
The lyophilised and milled tempehs were defatted with hexane, in a 1:10 ratio $(\mathrm{w} / \mathrm{v})$, for 1 hour at room temperature by continuous and rotary agitation, followed by vacuum filtration. The isoflavone extraction was performed in triplicate with $0.1 \mathrm{~g}$ of the defatted sample, using $2 \mathrm{~mL}$ of an extraction solution containing ultrapure water, acetone and ethanol $(1: 1: 1, \mathrm{v} / \mathrm{v} / \mathrm{v})$ (Yoshiara et al., 2012). The separation and quantification of isoflavones were performed in triplicate, using an ultraperformance liquid chromatography (UPLC) system, as described by Handa et al. (2014). Since different isoflavone forms have different molecular masses, in order to improve the comparisons, the isoflavone concentrations were expressed in micromoles of isoflavones per grams of lyophilized and defatted tempeh.

\section{Results and Discussion}

Grains of 'BRS 267' soybean cultivar had the following isoflavone components quantified by UPLC: $1.48 \mu \mathrm{mol} \quad \beta$-glucoside isoflavones $\mathrm{g}^{-1}$ (1.12 $\mu \mathrm{mol}$ genistin $\mathrm{g}^{-1}$, and $0.36 \mu \mathrm{mol}$ daidzin $\left.\mathrm{g}^{-1}\right), 4.25 \mu \mathrm{mol}$ malonylglucosides $\mathrm{g}^{-1}(3.04 \mu \mathrm{mol}$ malonylgenistin $\mathrm{g}^{-1}$, and $1.21 \mu \mathrm{mol}$ malonyldaidzin $\mathrm{g}^{-1}$ ), and only $0.33 \mu \mathrm{mol}$ genistein $\mathrm{g}^{-1}$. The aglycone forms were present in lower concentrations than the other isoflavone forms (Carrão-Panizzi et al., 2003). However, this same cultivar, harvested at different times and with isoflavones quantification by high performance liquid chromatography (HPLC), showed the following contents (Silva et al., 2009; Bavia et al., 2012): $2.16 \mu \mathrm{mol}$ daidzin $\mathrm{g}^{-1}$, $1.71 \mu \mathrm{mol}$ genistin $\mathrm{g}^{-1}, 2.33 \mu \mathrm{mol}$ malonyldaidzin $\mathrm{g}^{-1}$, $1.70 \mu \mathrm{mol}$ malonylgenistin $\mathrm{g}^{-1}, 0.24 \mu \mathrm{mol}$ daidzein $\mathrm{g}^{-1}$, and $0.80 \mu \mathrm{mol}$ genistein $\mathrm{g}^{-1}$. This differences in isoflavone contents can be attributed to the genetic variability and to different environmental conditions (Wang \& Murphy, 1996; Carrão-Panizzi et al., 2003).

The $\mathrm{X}_{1}$ variable (soaking time, $\mathrm{h}$ ) showed a significant linear negative effect $\left(\beta_{1} \mathrm{x}_{1}=-0.05 \mathrm{x}_{1}\right.$, $\mathrm{p}<0.05$ ) on the $\mathrm{Y}_{1}$ response function $(\mu \mathrm{mol}$ of genistin per $g$ of tempeh). The effects of the $\mathrm{X}_{2}$ (cooking time, $\min$ ) and $X_{3}$ (fermentation time, $h$ ) were not significant $(\mathrm{p}>0.05)$. Based only in the significant variable, the mathematical model $\hat{\mathrm{Y}}_{1}=0.24-0.05 \mathrm{x}_{1}$ was developed, indicating that the genistin level in tempeh is independent of the cooking and fermentation times. 
The lack-of-fit of the model was not significant (at 95\% confidence interval), and $77 \%$ of the experimental data were properly adjusted $\left(\mathrm{R}^{2}\right)$ to the model. The response surface (Figure $1 \mathrm{~A}$ ) and the desirability parameters (Figure $1 \mathrm{~B}$ ) showed a region where $\mathrm{Y}_{1}$ was maximum $\left(\hat{\mathrm{Y}}_{1}=0.40 \mu \mathrm{mol} \mathrm{g}{ }^{-1}\right)$, and obtained when the following conditions were used: $\mathrm{x}_{1}=-1$ or $\mathrm{X}_{1}=6 \mathrm{~h}$ of soaking; $\mathrm{x}_{2}=0.5$ or $\mathrm{X}_{2}=22.5$ min of cooking; and $\mathrm{x}_{3}=-1$ or $\mathrm{X}_{3}=18 \mathrm{~h}$ of fermentation with Rhizopus oligosporus. These processing conditions of soybean tempeh agreed with the assay 3 , in which the experimentally obtained $\mathrm{Y}_{1}$ was $0.40 \mu \mathrm{mol}$ of genistin per $\mathrm{g}$ of tempeh.

Genistin content in the tempeh was $36 \%$ lower $\left(0.40 \mu \mathrm{mol} \mathrm{g}^{-1}\right)$ than in the grains $\left(1.12 \mu \mathrm{mol} \mathrm{g}^{-1}\right)$, and daidzin content was neglectable (while its contents in the grains were $0.36 \mu \mathrm{mol} \mathrm{g}^{-1}$ ).

For the $\mathrm{Y}_{2}$ response function ( $\mu \mathrm{mol}$ of malonyldaidzin per $g$ of tempeh), the $\mathrm{X}_{2}$ (cooking time, min) and $\mathrm{X}_{3}$ (fermentation time, $\mathrm{h}$ ) variables showed significant linear negative effects $\left(\beta_{2} \mathrm{x}_{2}=-0.21 \mathrm{x}_{1}\right.$ and $\beta_{3} x_{3}=-0.05 x_{3}$, respectively), and the interaction between $X_{1}$ and $X_{2}$ resulted in a significant linear positive effect $\left(\beta_{12} \mathrm{X}_{1} \mathrm{X}_{2}=0.07 \mathrm{x}_{1} \mathrm{x}_{2}\right)(\mathrm{p}<0.05)$. The other effects were not significant, and the following mathematical model was developed: $\hat{\mathrm{Y}}_{2}=0.32-0.21 \mathrm{x}_{2}-0.05 \mathrm{x}_{3}+0.07 \mathrm{x}_{1} \mathrm{x}_{2}$. The lack-of-fit of the model was not significant (at
$95 \%$ ), and $95 \%$ of the experimental data were properly adjusted $\left(\mathrm{R}^{2}\right)$ to the model.

For the $\mathrm{Y}_{3}$ response function ( $\mu \mathrm{mol}$ malonylgenistin per $g$ of tempeh), the $X_{1}$ (soaking time, $h$ ), $X_{2}$ (cooking time, $\mathrm{min}$ ), and $\mathrm{X}_{3}$ (fermentation time, $\mathrm{h}$ ) variables showed significant linear negative effects $\left(\beta_{1} x_{1}=-0.11 x_{1}, \beta_{2} x_{2}=-0.46 x_{2}\right.$ and $\beta_{3} x_{3}=-0.09 x_{3}$, respectively). The interaction between $X_{1}$ and $X_{2}$ variables had a significant linear positive effect $\left(\beta_{12} \mathrm{x}_{1} \mathrm{x}_{2}=0.134 \mathrm{x}_{1} \mathrm{x}_{2}\right) \quad(\mathrm{p}<0.05)$. The other effects were not significant, and the mathematical model $\hat{\mathrm{Y}}_{3}=1.11-0.11 \mathrm{x}_{1}-0.46 \mathrm{x}_{2}-0.09 \mathrm{x}_{3}+0.13 \mathrm{x}_{1} \mathrm{x}_{2}$ was developed, indicating that low levels of the three variables $\left(\mathrm{X}_{1}, \mathrm{X}_{2}\right.$, and $\left.\mathrm{X}_{3}\right)$ are recommended, in order to prepare tempeh with the maximum malonyl content. The lack-of-fit of the model was not significant (at 95\%), and $99 \%$ of the experimental data were properly adjusted $\left(\mathrm{R}^{2}\right)$ to the model. The response surface (Figure $2 \mathrm{~A}$ and $\mathrm{C}$ ) and desirability parameters (Figure $2 \mathrm{~B}$ and $\mathrm{D}$ ) suggested a region where $\mathrm{Y}_{2}\left(0.58 \mu \mathrm{mol}\right.$ malonyldaidzin $\left.\mathrm{g}^{-1}\right)$ and $\mathrm{Y}_{3}$ $\left(2.01 \mu \mathrm{mol}\right.$ malonylgenistin $\left.\mathrm{g}^{-1}\right)$ were maximal, with the following conditions: $\mathrm{x}_{1}=-1$ or $\mathrm{X}_{1}=6 \mathrm{~h}$ soaking time; $\mathrm{x}_{2}=-1$ or $\mathrm{X}_{2}=15$ cooking time; and $\mathrm{x}_{3}=0$ or $\mathrm{X}_{3}=24 \mathrm{~h}$ fermentation time. These conditions coincided with the assay 1 , in which $\mathrm{Y}_{2}\left(0.58 \mu \mathrm{mol}\right.$ malonyldaidzin $\left.\mathrm{g}^{-1}\right)$
A

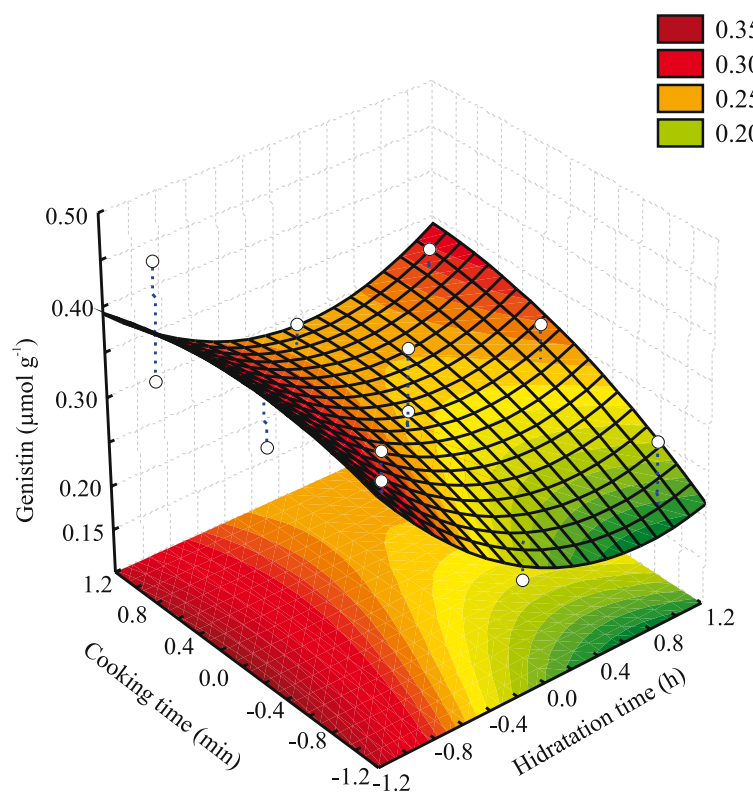

$\mathrm{B}$

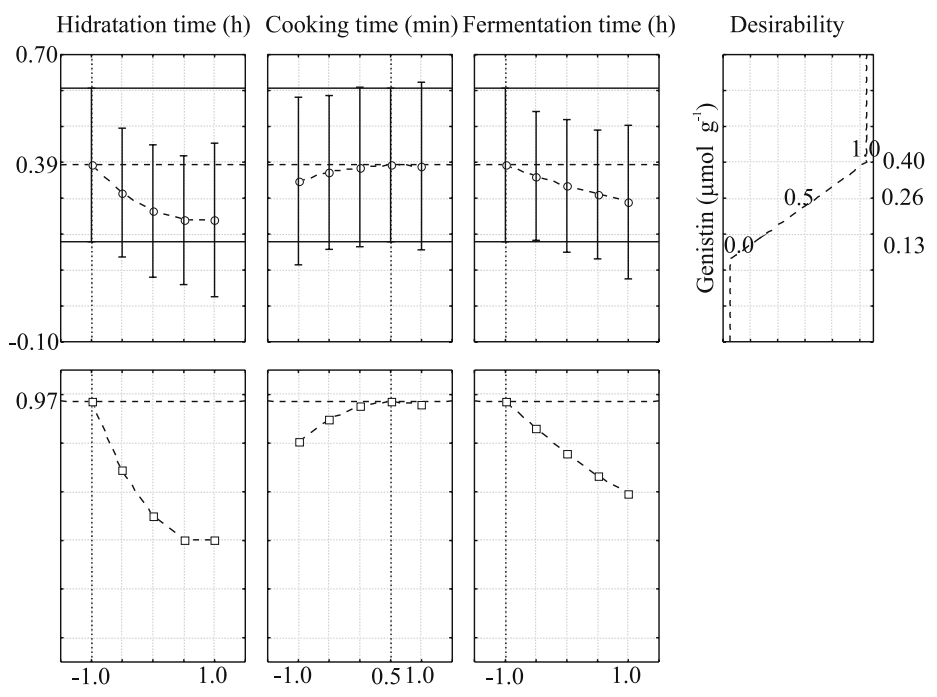

Figure 1. Response surface (A) and desirability parameters (B) for the response function $\mathrm{Y}_{1}$ ( $\mu$ mol of genistin $\mathrm{g}^{-1}$ of tempeh). 
and $\mathrm{Y}_{3}\left(2.02 \mu \mathrm{mol}\right.$ malonylgenistin $\left.\mathrm{g}^{-1}\right)$ were experimentally obtained. In the grains, the contents of malonylglucosides were $4.25 \mu \mathrm{mol} \mathrm{g}^{-1}$, with $3.04 \mu \mathrm{mol}$ malonylgenistin $\mathrm{g}^{-1}$.

The $\mathrm{X}_{2}$ variable (cooking time, $\mathrm{min}$ ) showed a significant linear negative effect $\left(\beta_{2} \mathrm{X}_{2}=-0.01 \mathrm{x}_{2}\right)$ on the $Y_{4}$ response function ( $\mu \mathrm{mol}$ of daidzein per $\mathrm{g}$ of tempeh). The $X_{1}$ and $X_{3}$ variables showed a significant quadratic effect $\left(\beta_{1} \mathrm{x}_{1}{ }^{2}=0.01 \mathrm{x}_{1}{ }^{2}\right.$ and $\beta_{3} \mathrm{x}_{3}{ }^{2}=-0.01 \mathrm{x}_{3}{ }^{2}$, respectively). The interaction between $\mathrm{X}_{1}$ (soaking time, $h$ ) and $X_{2}$ showed a significant linear positive effect $\left(\beta_{12} \mathrm{x}_{1} \mathrm{X}_{2}=0.01 \mathrm{x}_{1} \mathrm{x}_{2}\right)$, and the interactions between
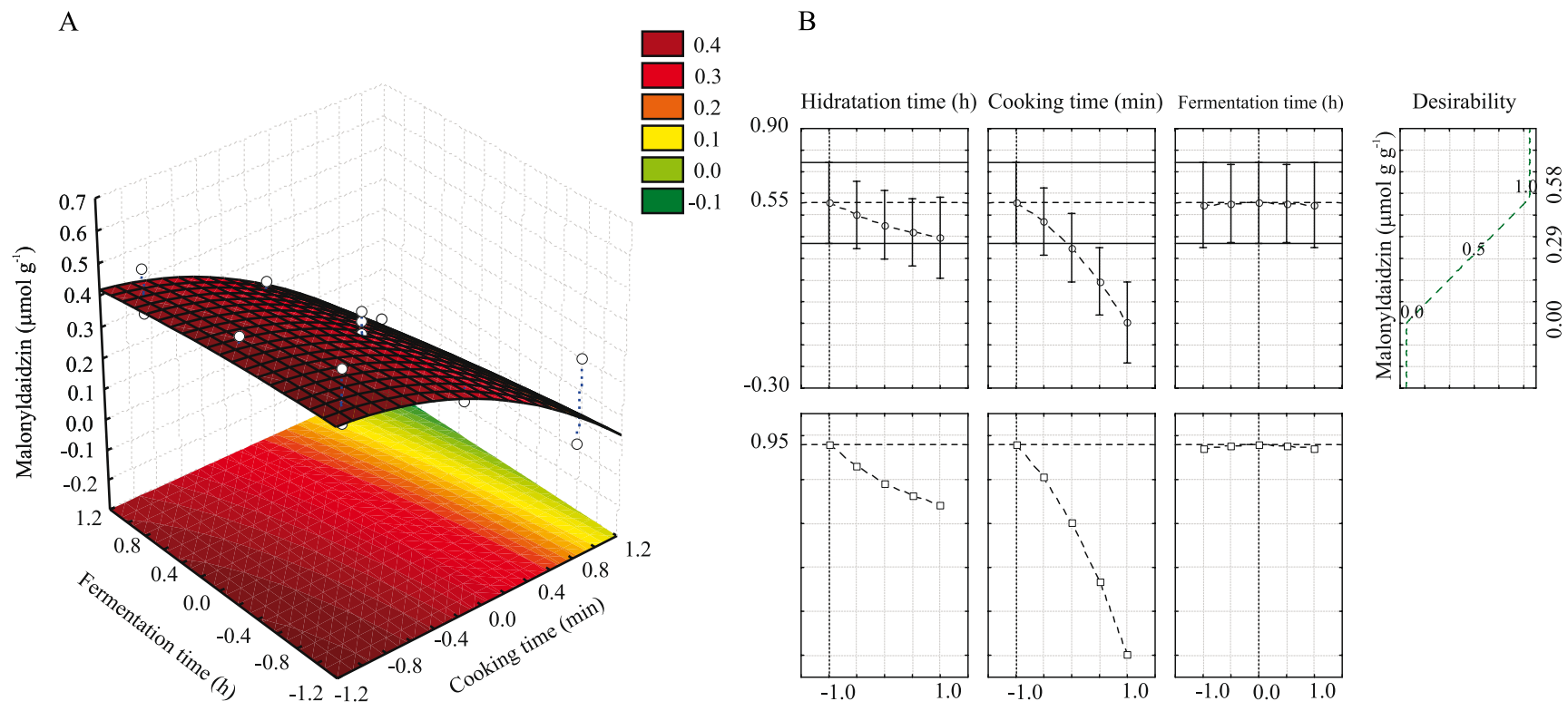

$\mathrm{C}$

D
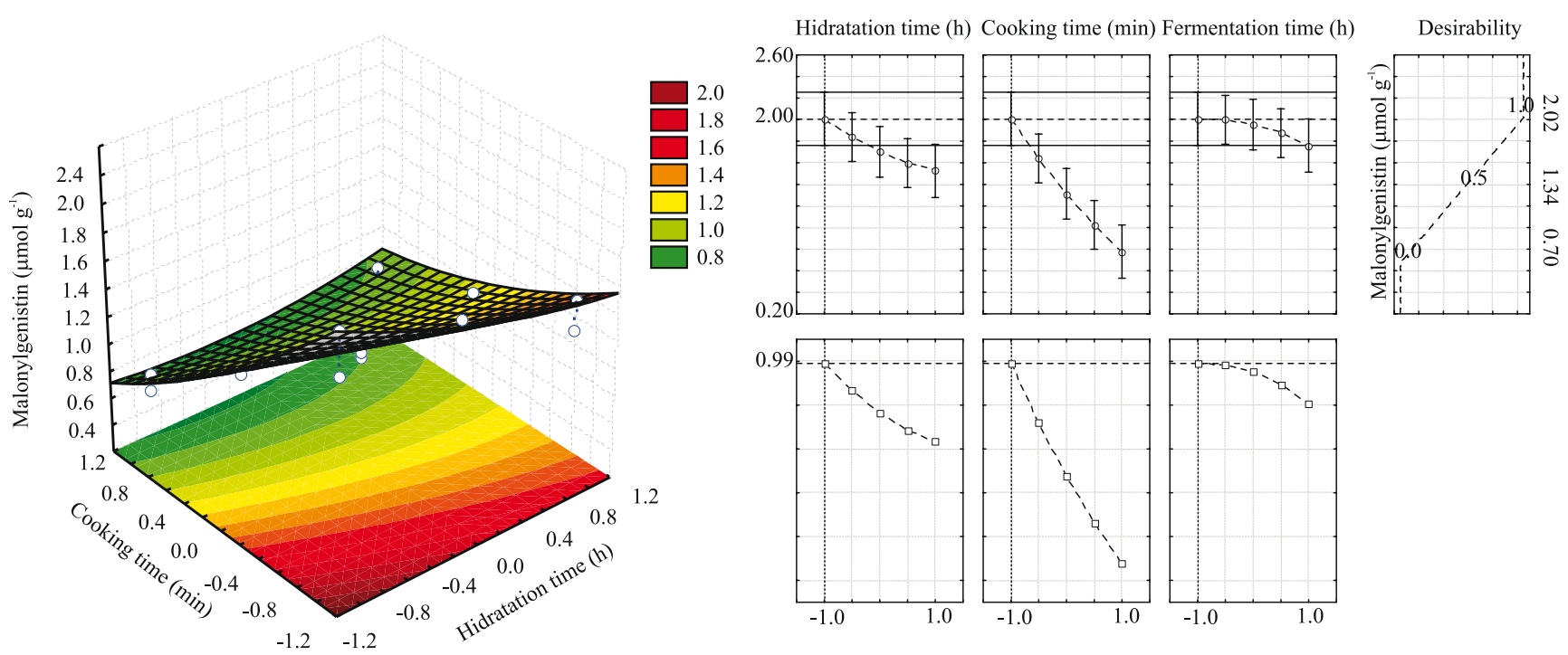

Figure 2. Response surface (A and $C$ ) and desirability parameters ( $B$ and $C$ ) for the response functions $\mathrm{Y}_{2}$ ( $\mu$ mol malonyldaidzin $\left.\mathrm{g}^{-1}\right)$ and $\mathrm{Y}_{3}\left(\mu \mathrm{mol}\right.$ malonylgenistin $\left.\mathrm{g}^{-1}\right)$. 
$\mathrm{X}_{1}$ and $\mathrm{X}_{3}$ (fermentation time, $\mathrm{h}$ ) and $\mathrm{X}_{2}$ and $\mathrm{X}_{3}$ showed significant linear negative effects $\left(\beta_{13} \mathrm{x}_{1} \mathrm{x}_{3}=-0.01 \mathrm{x}_{1} \mathrm{x}_{3}\right.$ and $\beta_{23} \mathrm{x}_{2} \mathrm{x}_{3}=-0.01 \mathrm{x}_{2} \mathrm{x}_{3}$, respectively) $(\mathrm{p}<0.05)$. The other effects were not significant, and the mathematical model $\hat{\mathrm{Y}}_{4}=0.08+0.01 \mathrm{x}_{1}{ }^{2}-0.01 \mathrm{x}_{2}-0.01 \mathrm{x}_{3}{ }^{2}+0.01 \mathrm{x}_{1} \mathrm{X}_{2}$ $-0.01 \mathrm{x}_{1} \mathrm{x}_{3}-0.01 \mathrm{x}_{2} \mathrm{x}_{3}$ was developed. The lack-of-fit of the model was not significant (at 95\%), and 90\% of the experimental data were properly adjusted $\left(\mathrm{R}^{2}\right)$ to the model. The response surface (Figure $3 \mathrm{~A}$ ) and desirability parameters (Figure $3 \mathrm{~B}$ ) suggested a region where $\hat{\mathrm{Y}}_{4}\left(\hat{\mathrm{Y}}_{4}=0.11 \mu \mathrm{mol} \mathrm{g} \mathrm{g}^{-1}\right)$ was maximal, when obtained by using the following conditions: $\mathrm{x}_{1}=-1$ or $\mathrm{X}_{1}=6 \mathrm{~h}$ soaking time; $\mathrm{x}_{2}=-1$ or $\mathrm{X}_{2}=15 \mathrm{~min}$ cooking time; and $\mathrm{x}_{3}=+0.5$ or $\mathrm{X}_{3}=30 \mathrm{~h}$ fermentation

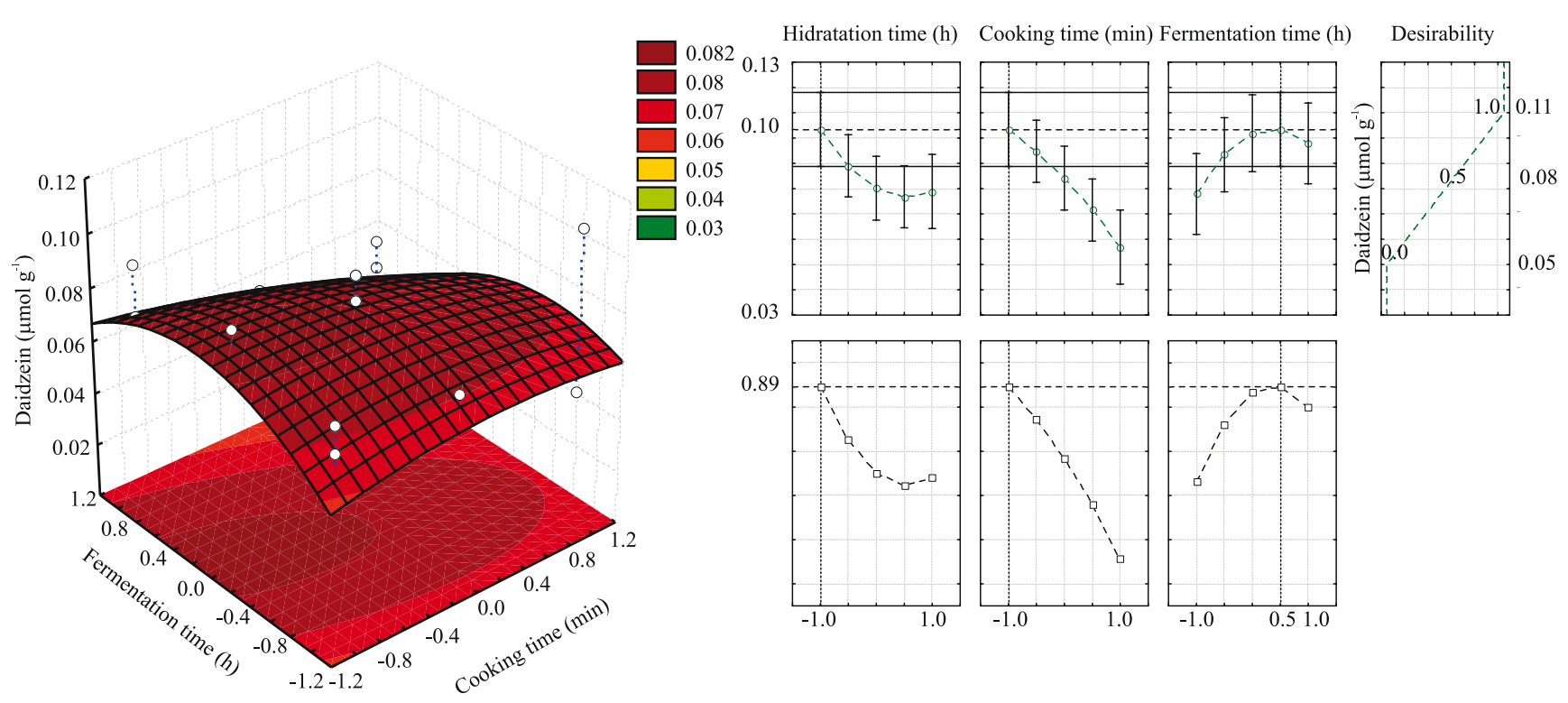

$\mathrm{C}$

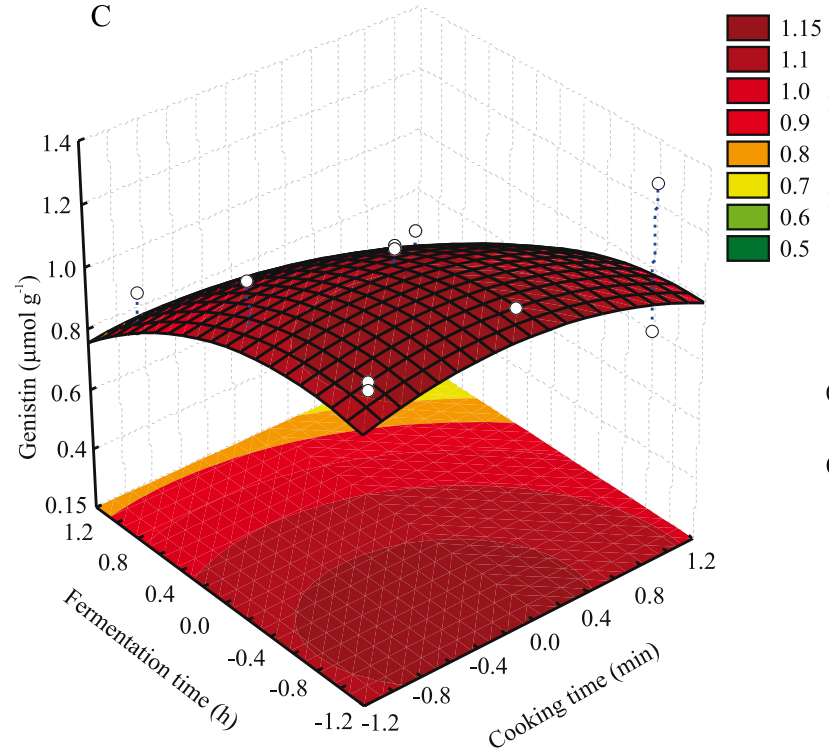

$\mathrm{D}$

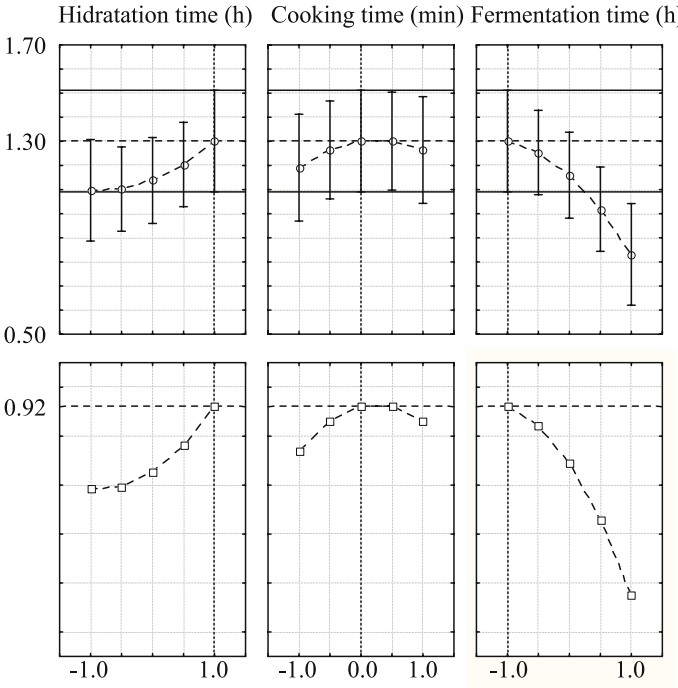

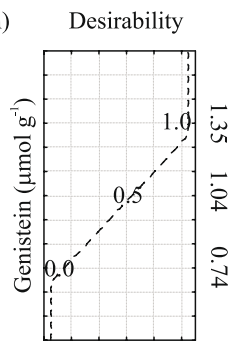

Figure 3. Response surfaces (A and C) and desirability parameters (B and D) for the response functions $\mathrm{Y}_{4}\left(\mu \mathrm{mol}\right.$ daidzein $\left.\mathrm{g}^{-1}\right)$ and $\mathrm{Y}_{5}\left(\mu \mathrm{mol} \mathrm{g} \mathrm{g}^{-1}\right.$ genistein $\left.\mathrm{g}^{-1}\right)$ 
time. This processing conditions did not differ from the assay 7 , in which the experimentally obtained $\mathrm{Y}_{4}$ was $0.11 \mu \mathrm{mol}$ of daidzein per $\mathrm{g}$ of tempeh (Table 1). Therefore, according to the equation $\hat{\mathrm{Y}}_{4}$, in order to obtain the maximum daidzein content in the tempeh, it is recommended to use low levels of $\mathrm{x}_{1}(-1)$ or $\mathrm{X}_{1}(6 \mathrm{~h}$ of soaking); for $\mathrm{x}_{2}(-1)$ or $\mathrm{X}_{2}$ (15 min of cooking); for $\mathrm{x}_{3}(+0.5)$ or at least $\mathrm{X}_{3}(30 \mathrm{~h}$ of fermentation).

For the $Y_{5}$ response function ( $\mu \mathrm{mol}$ of genistein per $g$ of tempeh), only the $\mathrm{X}_{3}$ variable (fermentation time, h) showed significant linear negative effect $\left(\beta_{3} x_{3}=-0.17 x_{3}\right)(p<0.05)$. Based only in this significant variable, the mathematical model $\hat{\mathrm{Y}}_{5}=1.07-0.17 \mathrm{x}_{3}$ was developed. The lack-of-fit of the model was not significant (at $95 \%$ ), and $86 \%$ of the experimental data were properly adjusted $\left(\mathrm{R}^{2}\right)$ to the model. The response surface (Figure $3 \mathrm{C}$ ) and desirability parameters (Figure $3 \mathrm{D}$ ) suggested that the maximum genistein content $\left(\hat{Y}_{5}=1.35 \mu \mathrm{mol} \mathrm{g}^{-1}\right)$ was obtained when using the following conditions: $\mathrm{x}_{1}=+1$ or $\mathrm{X}_{1}=18 \mathrm{~h}$ of soaking time; $\mathrm{x}_{2}=0$ or $\mathrm{X}_{2}=20$ min of cooking time; and $\mathrm{x}_{3}=-1$ or $\mathrm{X}_{3}=18 \mathrm{~h}$ of fermentation time. This estimated result of the maximum genistein content coincided with the assay $7\left(\mathrm{Y}_{5}=1.35 \mu \mathrm{mol} \mathrm{g}^{-1}\right)$ (Table 1). Therefore, according to the equation $\hat{\mathrm{Y}}_{5}$, in order to obtain a higher genistein content in tempeh, it is recommended to use the lower level condition $\left(\mathrm{x}_{3}=-1\right.$ or $18 \mathrm{~h}$ fermentation time), which was independent of the $\mathrm{X}_{1}$ or $\mathrm{X}_{2}$ variables.

Based on the confidence interval (CI) of the assay $7(\mathrm{CI}=1.03$ to 1.49$)$, and on the response functions of the assays $1,5,9,10,11,13,16$, and 17 where $\mathrm{x}_{3}=-1$, all response functions were within the interval of the assay 7 , confirming that $\mathrm{X}_{1}$ (soaking time) and $\mathrm{X}_{2}$ (cooking time) were independent variables to obtain tempehs with maximum genistein content. In the grains, 'BRS 267' showed only $0.33 \mu \mathrm{mol} \mathrm{g}{ }^{-1}$. For tempeh obtained in the assay 7 , the aglycone levels $\left(0.11 \mu \mathrm{mol}\right.$ daidzein $\mathrm{g}^{-1}$ and $1.35 \mu \mathrm{mol}$ genistein $\left.\mathrm{g}^{-1}\right)$ increased by 4.4 times, mainly due to the fermentation of cotyledons.

The processing variables for tempeh preparation changed the level, profile, and distribution of the different isoflavone forms (Table 1). However, when comparing tempeh with cooked soybean grains, tempeh showed a $57 \%$ reduction in the content of glucosides, and the aglycone levels increased 6.5 fold due to the action of $\beta$-glucosidase produced by the fungus during fermentation (Wang \& Murphy, 1996). The cooking of soybean grains does not change the profile or distribution of the isoflavones, but it causes a drastic reduction in malonylglucosides. The isoflavone malonyl forms are unstable at high temperatures and are converted into their respective $\beta$-glycosides forms, due to the cleavage of malonyl ester groups, to daidzin and genistin forms. Kudou et al. (1991) reported that the content of malonylglucosides increased, after 12 to $24 \mathrm{~h}$ of fermentation. Bavia et al. (2012) observed an increase of $78 \%$ in the content of isoflavone aglycones

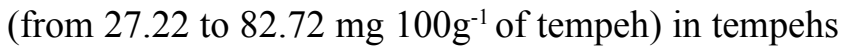
prepared from different soybean cultivars. The authors also observed an increase of 15.01 to $26.74 \mathrm{mg} 100 \mathrm{~g}^{-1}$ in tempeh by soaking for $17 \mathrm{~h}$, cooking for $30 \mathrm{~min}$, and fermenting for $26 \mathrm{~h}$. In the present work, the fermentation for $24 \mathrm{~h}$ resulted in the conversion of glycosides isoflavones and in the increase of the concentration of the corresponding aglycones, which agrees with other studies (Nakajima et al., 2005; Haron et al., 2009; Ferreira et al., 2011; Villares et al., 2011). However, in the process of fermentation, despite the nonsignificant losses of isoflavones, the $\beta$-glycosidase enzyme hydrolyzes $\beta$-glucosides forms to aglycones, which have high biological activity and are the isoflavones readily available to humans (Izumi et al., 2000).

Therefore, the models established the following conditions to obtain tempeh with maximum content of different isoflavone forms, which would favor its classification as a functional food: $\mathrm{x}_{1}(-1)$, for genistin; $\mathrm{x}_{1}, \mathrm{x}_{2}$, and $\mathrm{x}_{3}(-1,-1$, and 0$)$, for malonyl; $\mathrm{x}_{1}, \mathrm{x}_{2}$, and $\mathrm{x}_{3}(-1)$, for daidzein; and $\mathrm{x}_{3}(-1)$, for genistein. To achieve the maximum content of different isoflavone forms, including aglycones, it is recommended to use the minimal amount of time for the processing variables, which corresponded to the assay 1 , as follows: $6 \mathrm{~h}$ of soaking, $15 \mathrm{~min}$ of cooking and $18 \mathrm{~h}$ of fermentation.

\section{Conclusions}

1. In the preparation of soybean tempeh, the processing variables including soaking, cooking, and fermentation times with Rhizopus oligosporus change the level, profile, and distribution of the different isoflavone forms.

2 . The highest bioconversion of $\beta$-glycoside isoflavones into aglycones occurs when soybean grains are soaked for $6 \mathrm{~h}$, cotyledons are cooked for $15 \mathrm{~min}$, and the fermentation with $R$. oligosporus lasts for $18 \mathrm{~h}$. 


\section{Acknowledgements}

To Conselho Nacional de Desenvolvimento Científico e Tecnológico, for funding and for scholarships; to Fundação Araucária, Paraná, PR, Brazil, for funding.

\section{References}

ARJMANDI, B.H.; ALEKEL, L.; HOLLIS, B.W.; AMIN, D.; STACEWICZ-SAPUNTZAKIS, M.; GUO, P.; KUKREJA, S.C. Dietary soybean protein prevents bone loss in an ovariectomized rat model of osteoporosis. Journal of Nutrition, v.126, p.161-167, 1996.

BAVIA, A.C.F.; SILVA, C.E. da; FERREIRA, M.P.; SANTOS LEITE, R.; MANDARINO, J.M.G.; CARRÃO-PANIZZI, M.C. Chemical composition of tempeh from soybean cultivars specially developed for human consumption. Ciência e Tecnologia de Alimentos, v.32, p.613-620, 2012. DOI: 10.1590/ S0101-20612012005000085.

CARRÃO-PANIZZI, M.C.; SIMÃO, A.S.; KIKUCHI, A. Efeitos de genótipos, ambientes e de tratamentos hidrotérmicos na concentração de isoflavonas agliconas em grãos de soja. Pesquisa Agropecuária Brasileira, v.38, p.897-902, 2003. DOI: 10.1590/ S0100-204X2003000800001.

CHANG, C.-T.; HSU, C.-K.; CHOU, S.-T.; CHEN, Y.-C.; HUANG, F.-S.; CHUNG, Y.-C. Effect of fermentation time on the antioxidant activities of tempeh prepared from fermented soybean using Rhizopus oligosporus. International Journal of Food Science and Technology, v.44, p.799-806, 2009. DOI: 10.1111/j.1 365-2621.2009.01907.x.

FERREIRA, M.P.; OLIVEIRA, M.C.N. de; MANDARINO, J.M.G.; SILVA, J.B. da; IDA, E.I.; CARRÃO-PANIZZI, M.C. Changes in the isoflavone profile and in the chemical composition of tempeh during processing and refrigeration. Pesquisa Agropecuária Brasileira, v.46, p.1555-1561, 2011. DOI: 10.1590/ S0100-204X2011001100018.

HANDA, C.L.; COUTO, U.R.; VICENSOTI, A.H.; GEORGETTI, S.R.; IDA, E.I. Optimisation of soy flour fermentation parameters to produce $\beta$-glucosidase for bioconversion into aglycones. Food Chemistry, v.152, p.56-65, 2014. DOI: 10.1016/j. foodchem.2013.11.101.

HARON, H.; ISMAIL, A.; AZLAN, A.; SHAHAR, S.; PENG, L.S. Daidzein and genestein contents in tempeh and selected soy products. Food Chemistry, v.115, p.1350-1356, 2009. DOI: 10.1016/j.foodchem.2009.01.053.

IZUMI, T.; PISKULA, M.K.; OSAWA, S.; OBATA, A.; TOBE, K.; SAITO, M.; KATAOKA, S.; KUBOTA, Y.; KIKUCHI, M. Soy isoflavone aglycones are absorbed faster and in higher amounts than their glucosides in humans. Journal of Nutrition, v.130, p.1695-1699, 2000.

KUDOU, S.; FLEURY, Y; WELTI, D.; MAGNOLATO, D.; UCHIDA, T.; KITAMURA, K.; OKUBO, K. Malonyl isoflavone glycosides in soybean seeds (Glycine max Merrill). Agricultural and Biological Chemistry, v.55, p.2227-2233, 1991. DOI: 10.1271/bbb1961.55.2227.
LIGGINS, J.; BLUCK, L.J.C.; RUNSWICK, S.; ATKINSON, C.; COWARD, W.A.; BINGHAM, S.A. Daidzein and genistein contents of vegetables. British Journal of Nutrition, v.84, p.717-725, 2000. DOI: 10.1017/S0007114500002075.

LUND, T.D.; MUNSON, D.J.; HALDY, M.E.; SETCHELL, K.D.R; LEPHART, E.D.; HANDA, R.J. Equol is a novel anti-androgen that inhibits prostate growth and hormone feedback. Biology of Reproduction, v.70, p.1188-1195, 2004. DOI: 10.1095/ biolreprod.103.023713.

MESSINA, M.; HUGHES, C. Efficacy of soyfoods and soybean isoflavone supplements for alleviating menopausal symptoms is positively related to initial hot flash frequency. Journal of Medicinal Food, v.6, p.1-11, 2003. DOI: 10.1089/109662003765184697.

MO, H.; KARILUOTO, S.; PIIRONEN, V.; ZHU, Y.; SANDERS, M.G.; VINCKEN, J.-P.; WOLKERS-ROOIJACKERS, J.; NOUT, M.J. R. Effect of soybean processing on content and bioaccessibility of folate, vitamin B12 and isoflavones in tofu and tempe. Food Chemistry, v.141, p.2418-2425, 2013. DOI: 10.1016/j.foodchem.2013.05.017.

MUROOKA, Y.; YAMASHITA, M. Traditional healthful fermented products of Japan. Journal of Industrial Microbiology and Biotechnology, v.35, p.791-798, 2008. DOI: 10.1007/ s10295-008-0362-5.

NAKAJIMA, N.; NOZAKI, N.; ISHIHARA, K.; ISHIKAWA, A.; TSUJI, H. Analysis of isoflavone content in tempeh, a fermented soybean, and preparation of a new isoflavone-enriched tempeh. Journal of Bioscience and Bioengineering, v.100, p.685-687, 2005. DOI: $10.1263 / \mathrm{jbb} .100 .685$.

NOUT, M.J.R.; KIERS, J.L. Tempe fermentation, innovation and functionality: update into the third millenium. Journal of Applied Microbiology, v.98, p.789-805, 2005. DOI: 10.1111/j.1365-2672. 2004.02471.x.

SARKAR, F.H.; LI, Y. Soy isoflavones and cancer prevention. Cancer Investigation, v.21, p.744-757, 2003. DOI: 10.1081/ CNV-120023773.

SHURTLEFF, W.; AOYAGI, A. The book of tempeh. $2^{\text {nd }} e d$. Berkeley: Ten Speed Press, 2001. p.103-113.

SILVA, J.B. da; CARRÃO-PANIZZI, M.C.; PRUDENCIO, S.H. Chemical and physical composition of grain-type and food-type soybean for food processing. Pesquisa Agropecuária Brasileira, v.44, p.777-784, 2009. DOI: 10.1590/S0100-204X2009000700019.

STARZYǸSKA-JANISZEWSKA， A.; STODOLAK, B.; MICKOWSKA, B. Effect of controlled lactic acid fermentation on selected bioactive and nutritional parameters of tempeh obtained from unhulled common bean (Phaseolus vulgaris) seeds. Journal of the Science of Food and Agriculture, v.94, p.359-366, 2014. DOI: $10.1002 /$ jsfa.6385.

UNITED STATES DEPARTMENT OF AGRICULTURE. National nutrient database for standard reference. 2008. Available at: $<$ http:// www.fns.usda.gov/tn/Resources/smi_appendices.pdf $>$. Accessed on: 10 May 2014.

VILLARES, A.; ROSTAGNO, M.A.; GARCÍA-LAFUENTE, A.; GUILLAMÓN, E.; MARTÍNEZ, J.A. Content and profile of isoflavones in soy-based foods as a function of the production 
process. Food and Bioprocess Technology, v.4, p. 27-38, 2011. DOI: 10.1007/s11947-009-0311-y.

WANG, H.-J.; MURPHY, P.A. Mass balance study of isoflavones during soybean processing. Journal of Agricultural and Food Chemistry, v.44, p.2377-2383, 1996. DOI: 10.1021/jf950535p.

WEI, L.S. Domestic soybean consumption in Asia. In: TANTEERATARM, K. (Ed.). Soybean processing for food uses. Urbana: INTSOY: University of Illinois, 1991. p.162-183.
YOSHIARA, L.Y.; MADEIRA, T.B.; DELAROZA, F.; SILVA, J.B. da; IDA, E.I. Optimization of soy isoflavone extraction with different solvents using the simplex-centroid mixture design. International Journal of Food Science and Nutrition, v.63, p.978-986, 2012. DOI: 10.3109/09637486.2012.690026.

ZHUO, X.-G.; MELBY, M.K.; WATANABE, S. Soy isoflavone intake lowers serum LDL cholesterol: a meta-analysis of 8 randomized controlled trials in humans. Journal of Nutrition, v.134, p.2395-2400, 2004.

Received on May 28, 2015 and accepted on January 28, 2016 